\title{
The Cystic Fibrosis Intestine
}

\author{
Robert C. De Lisle ${ }^{1}$ and Drucy Borowitz ${ }^{2}$ \\ ${ }^{1}$ Anatomy and Cell Biology, University of Kansas School of Medicine, Kansas City, Kansas 66160 \\ ${ }^{2}$ State University of New York at Buffalo School of Medicine and Biomedical Sciences, Women \\ and Children's Hospital of Buffalo, Buffalo, New York 14222 \\ Correspondence: rdelisle@kumc.edu
}

\begin{abstract}
The clinical manifestations of cystic fibrosis (CF) result from dysfunction of the cystic fibrosis transmembrane regulator protein (CFTR). The majority of people with CF have a limited life span as a consequence of CFTR dysfunction in the respiratory tract. However, CFTR dysfunction in the gastrointestinal (Gl) tract occurs earlier in ontogeny and is present in all patients, regardless of genotype. The same pathophysiologic triad of obstruction, infection, and inflammation that causes disease in the airways also causes disease in the intestines. This article describes the effects of CFTR dysfunction on the intestinal tissues and the intraluminal environment. Mouse models of CF have greatly advanced our understanding of the GI manifestations of CF, which can be directly applied to understanding CF disease in humans.
\end{abstract}

$T^{\text {he }}$ he gene responsible for CF is CFTR, a cyclic adenosine monophosphate (cAMP)-regulated anion channel expressed at high levels in various epithelia and at much lower levels in many other cell types. As in most other epithelial organs, CFTR in the intestine mediates secretion of chloride, bicarbonate, and fluid. Mutations in the CFTR gene may result in partial or total loss of function (see Ferec and Cutting 2012), resulting in secreted fluid with abnormally low volume and aberrant electrolyte composition. The altered milieu on the epithelial surface is believed to be the major cause of pathogenesis in affected organs, including the intestine. This review will focus on pathologies of the intestine, including how luminal functions (digestion, host-microbial interactions) are affected, and therapeutic interventions based on our understanding of CF pathogenesis in the intestine.

\section{CFTR DISTRIBUTION IN THE INTESTINE}

The CFTR gene is weakly expressed in the stomach, but is more strongly expressed all along the intestinal tract (Strong et al. 1994). There is a cephalad-caudad gradient with CFTR messenger RNA (mRNA) levels highest in the duodenum, including high expression in the mucus secreting Brunner's glands, and levels decrease distally along the small intestine to the ileum. There is moderate CFTR expression in the large intestine. There is also a gradient of expression along the crypt-villus axis with greatest expression in the crypts in the small intestine and near the base of the crypts in the large intestine. Even though CFTR mRNA levels show a strong cryptto-surface gradient, this is not necessarily indicative of protein levels. Immunolocalization data for the small intestine show CFTR protein levels in the villi that exceed predictions based on very

Editors: John R. Riordan, Richard C. Boucher, and Paul M. Quinton

Additional Perspectives on Cystic Fibrosis available at www.perspectivesinmedicine.org

Copyright (C) 2013 Cold Spring Harbor Laboratory Press; all rights reserved; doi: 10.1101/cshperspect.a009753

Cite this article as Cold Spring Harb Perspect Med 2013;3:a009753 
R.C. De Lisle and D. Borowitz

low mRNA levels in these cells (Jakab et al. 2011). It has been suggested that because enterocytes have a short life span on the intestinal villi (3-5 d), CFTR protein can be synthesized in crypt cells where its mRNA is more abundant, and the protein product may last for the time that it takes the cells to migrate from the crypt up to the villus tip where they turn over.

The localization of CFTR expression in the intestine reflects the need for bicarbonate and fluid secretion. Bicarbonate secretion is highest in the proximal intestine that receives a high acid load from the stomach. This acidity is normally neutralized by bicarbonate to support optimal activity of digestive enzymes from the exocrine pancreas and solubility of bile salts from the biliary tract (Carey 1984). When CFTR function is deficient, gastric acid is not properly neutralized in the intestine and this contributes to poor digestive function in the intestine. Although the intestine is often thought of as an absorbing tissue, it also secretes significant volumes of fluid, largely from the crypts that have high CFTR levels, where it is thought to flush out this cul-de-sac to maintain a sterile environment to protect the stem cells at the bottom of the crypt. In addition, the intestine receives a large volume of bicarbonate-rich fluid from the pancreas (see Wilschanski and Novak 2013).

\section{CLINICAL CONSEQUENCES OF CF IN THE INTESTINE}

The gastrointestinal (GI) system is among the earliest parts of the body affected in CF, with a significant proportion of neonates showing damage. About $60 \%$ of patients with severe CFTR mutations (see article in this collection by Ferec and Cutting 2012) are born with exocrine pancreatic insufficiency (EPI) (Cipolli et al. 2007), which progresses with age to include $85 \%-90 \%$ of patients (see Wilschanski and Novak 2013). Loss of bicarbonate-rich pancreatic fluids in patients with EPI alters the intestinal intraluminal milieu. The lack of this major acid neutralizing power, the lack of fluid for hydration of the intestinal contents (Kopelman et al. 1985), and reduced enzymatic capacity to digest ingested food contributes in a multifactorial way to GI symptoms and signs. Of note, patients with CF who are pancreatic sufficient have decreased bicarbonate and volume secretion (Kopelman et al. 1988) but produce sufficient flow to allow adequate enzyme secretion for digestion.

The liver and biliary tract are also affected in CF but more variably so. CF-related liver disease occurs in 5\%-15\% of patients with CF (Lindblad et al. 1999; Colombo et al. 2006), usually in the first decade of life. Clinically significant CF liver disease rarely develops de novo in patients over age 18 (Bhardwaj et al. 2009). Even in CF patients without clinical liver disease there is fecal loss of bile acids (O'Brien et al. 1993), which can lead to poor micelle formation, contributing to fat and vitamin malabsorption. However, in CF mice fecal loss of bile salts does not appear to affect fat absorption (reviewed in Wouthuyzen-Bakker et al. 2011).

\section{Obstruction}

Most or perhaps all of the wide range of effects of CF on the gut are secondary to the decrease in anion and fluid transport caused by loss of CFTR function. Loss of CFTR function results in a relatively dehydrated luminal environment, and deficiency in this bicarbonate secretion results in prolonged postprandial acidity in the proximal small intestine (Dalzell and Heaf 1990; Robinson et al. 1990; Barraclough and Taylor 1996; Gelfond et al. 2012). A major consequence of the altered luminal environment is the accumulation of mucus in the CF intestine. Along with adequate fluid volume, bicarbonate appears to be crucial to the normal expansion and solubility of intestinal mucus (Garcia et al. 2009; Verdugo 2012). It can be argued that excessive mucus accumulation is the most important pathological event in CF disease, as this contributes to most of the other sequelae of this disease.

The most serious acute complication of the intestine in $\mathrm{CF}$ is obstruction of the terminal ileum or proximal large intestine, which if untreated can result in rupture and sepsis. Such obstruction in CF neonates is called meconium ileus (MI). Ileus means diminished or absent peristalsis, in this case associated with failure 

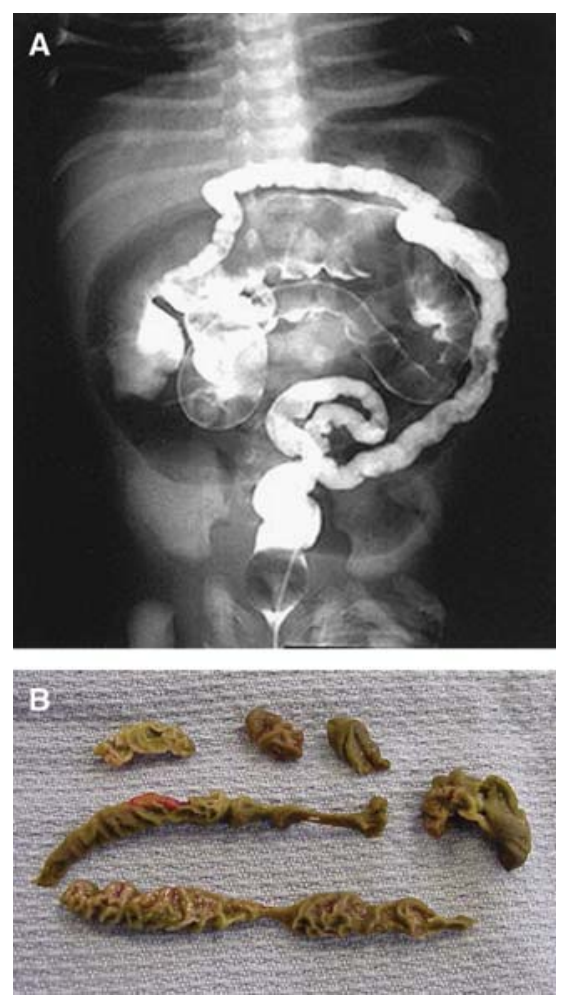

Figure 1. Obstruction of the intestines in CF. $(A)$ Microcolon of disuse with prestenotic dilatation, and $(B)$ meconium casts taken from an infant with cystic fibrosis and meconium ileus.

to pass meconium, the in utero intestinal contents. Normal meconium is already thick, being composed of shed intestinal epithelial cells, mucus, bile, amniotic fluid, and ingested fetal hair (lanugo). In CF, the meconium is more viscid in consistency and will even form casts of the intestine (Fig. 1). MI occurs in $\sim 20 \%$ of CF neonates (CF Foundation Patient Registry 2010, www.CFF.org) and is associated with severe CFTR mutations (Feingold and Guilloud-Bataille 1999). MI often can be treated by radiologically guided contrast enema with a solution containing a nonabsorbable osmolyte (e.g., Gastrograffin, 3,5-diacetamido-2,4,6-triiodobenzoic acid), which draws fluid into the intestine allowing the meconium to be flushed out. In some cases, surgical removal of the blockage with or without intestinal resection is required.
Obstruction can also occur in older CF patients and is called distal intestinal obstructive syndrome (DIOS) (Houwen et al. 2010). The material forming the obstruction in DIOS has been described as being "mucofeculant" to indicate its composition of mucus and fecal-type matter (undigested materials and a high content of bacteria). This material is very thick with a putty-like consistency that adheres strongly to the mucosal surface. A bubbly granular mass can be seen in the right lower quadrant on abdominal radiographs (Fig. 2). Similar to MI, DIOS is often successfully treated using osmotic agents (Cleghorn et al. 1986). Although MI and DIOS are similar they are likely distinct entities because less than half of patients that develop DIOS had MI as infants (Houwen et al. 2010). Also, genetic twin studies of CF patients showed the risk for development of DIOS is caused primarily by nongenetic (environmental) factors, whereas there is strong evidence for effects of modifier genes for the occurrence of MI (see Blackman et al. 2006; Knowles and Drumm 2012).

Chronic, low-grade obstruction is also present in patients with CF as constipation or ob-

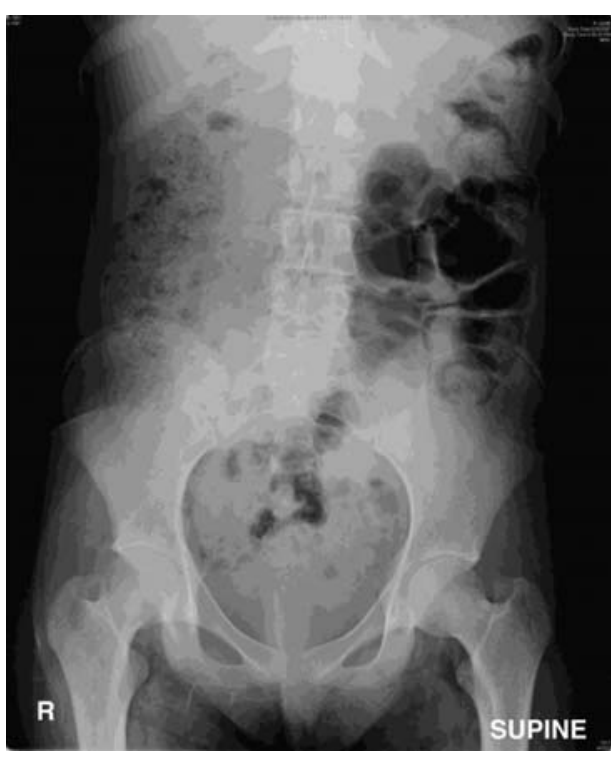

Figure 2. Bubbly granular mass in the right lower quadrant of a patient with distal intestinal obstruction syndrome (DIOS). 
stipation. The prevalence has been reported to be between $26 \%$ and $46 \%$ of patients with CF (Rubinstein et al. 1986; van der Doef et al. 2010). This condition exists even in patients having bowel movements each day. A diagnostic schema has recently been developed that is based on symptoms of abdominal pain or a change in frequency or consistency of stools, plus relief of symptoms by use of an osmotic laxative such as polyethylene glycol (Houwen et al. 2010). A potential new treatment is lubiprostone, which was approved for chronic idiopathic constipation in the general population in 2006. Lubiprostone, a synthetic eicosanoid, was originally shown to activate the CLC2 chloride channel (Cuppoletti et al. 2004), which enhances fluid secretion into the gut thus increasing bowel movements. The fact that lubiprostone targeted a non-CFTR mechanism makes it an attractive candidate for $\mathrm{CF}$ therapy. However, lubiprostone may act via prostaglandin receptors to activate CFTR (Bijvelds et al. 2009; Wood 2010). Despite this uncertainty, there are some positive data using human CF tissues (Joo et al. 2009). Recently, a case series was published on the use of lubiprostone as a treatment for chronic constipation in adults with CF (O'Brien et al. 2010). These definitions and the efficacy of treatments that focus on increasing intraluminal fluid suggest that chronic constipation or obstipation likely results primarily from poor hydration of the intestinal lumen in individuals with $\mathrm{CF}$.

\section{Microbial Dysbiosis}

One of the hallmarks of CF lung disease is the colonization of the usually nearly sterile airways with bacteria such as Staphylococcus aureus, Pseudomonas aeruginosa, and a range of other microorganisms. In contrast to the airways, the GI tract in healthy individuals is home to a wide variety of bacteria, the majority of which are localized to the cecum and colon, where they contribute to the bulk of fecal material. In patients with CF, the GI microbiota is altered in diversity, location, and cell density. In health, the summated actions of gastric acid, peristalsis, intestinal fluid, antibacterial proteins, and the ileocecal valve keep the quantity of bacteria in the small intestine at low levels. Failure of any of these mechanisms can lead to small intestinal bacterial overgrowth (SIBO), a syndrome that can result in diarrhea, abdominal distension, flatulence, steatorrhea, macrocytic anemia, and weight loss (Singh and Toskes 2003). Weight loss may result from bacterial competition for ingested nutrients, intestinal inflammation from enterotoxic metabolites, and the ability of bacteria to deconjugate bile acids, thus reducing their ability to emulsify fat (Hofmann and Mysels 1992).

The most commonly used diagnostic for SIBO is breath testing after ingestion of a test sugar (Braden 2009). This approach measures exhaled hydrogen or methane, which reports the time at which the test sugars encounter bacteria in the gut. Hydrogen and methane cannot be produced by host-cell metabolism but are the products of microbial fermentation; the magnitude of the gas levels is proportional to the concentration of bacteria. Using breath testing, SIBO has been found in about one-half of CF patients (Lewindon et al. 1998; Fridge et al. 2007; Lisowska et al. 2009, 2010). Also using breath testing, several studies have reported that orocecal transit is frequently slower in CF (Bali et al. 1983; Dalzell et al. 1990; Escobar et al. 1992; Murphy et al. 1992; Lewindon et al. 1998). Although breath testing is easy to perform, there are limitations that complicate interpretation and affect the sensitivity and specificity of this approach (for a review, see Braden 2009).

Mucus accumulation in the intestinal lumen in CF creates a niche for abnormal microbial colonization, which can lead to SIBO, a form of microbial dysbiosis. Detailed characterization of the bacteria that overgrow the human CF small intestine requires direct sampling by the invasive technique of endoscopy. There is also the issue of what region to sample (duodenal vs. ileal) and what type of sample (luminal content vs. mucosa) should be obtained to study bacteria in the intestine (Bhat et al. 1980). In CF, the bacteria are likely to be predominantly in the mucus as they are in the CF mouse (Norkina et al. 2004), which is poorly soluble and adheres to the gut wall. A full understanding of the microbiota of the CF small intestine may therefore 
require, in addition to luminal samples, biopsy of the intestinal tissue and the adherent mucus to have the best chance of obtaining appropriate samples. At present, only the most proximal small intestine can be biopsied nonoperatively, excluding the jejunum and proximal ileum from sampling. Although enteroscopy can be used to obtain both tissue and aspirates from these parts of the small bowel, it is not part of routine practice. Altered small intestinal microbiota is associated with several clinical conditions (Cotter 2011), but this has not been studied yet in CF.

Because of the complexity of the gut microbiota and the fact that the majority of these bacteria have never been cultured, molecular techniques are much more appropriate for such investigations than traditional culture-based approaches. This involves use of PCR amplification and either analysis by electrophoresis or by sequencing of the bacterial $16 S$ ribosomal gene, which has enough variability to identify bacteria often to the species level (Gill et al. 2006) and can be readily applied to the human fecal microbiota (Qin et al. 2010a,b). Analysis of the fecal microbiota is much easier than small intestine, and has begun to be applied to stool samples from patients with CF. One such study showed decreased species richness and less temporal stability of the CF fecal microbiota as compared with healthy controls (Duytschaever et al. 2012). Other work investigated early life development of the gut and airway microbiota in CF (Madan et al. 2012). The investigators suggested "that nutritional factors and gut colonization patterns are determinants of the microbial development of respiratory tract microbiota in infants with CF and present opportunities for early intervention in CF with altered dietary or probiotic strategies." Clearly, these are exciting times for novel insights into the roles of our microbiota in health and in disease.

In addition to the unique niche formed by static mucus in the CF intestine, there are other factors that contribute to microbial dysbiosis in CF, such as the need for periodic acute courses of antimicrobials as well as chronic antibacterial therapy to combat airway infections. Even when administered by inhalation, significant amounts of antibiotics will be ingested and thus also affect the gastrointestinal tract. Because large numbers of bacteria are normal residents of the healthy gut, antibiotic use is a two-edged sword (Sekirov et al. 2010). Antibiotic use suppresses normal commensal strains and can foster selective antibiotic-resistant bacterial overgrowth that will exploit the empty niche left by the eradicated organisms.

An important commensal organism commonly lost in CF owing to antibiotic use is $O x$ alobacter formigenes (Sidhu et al. 1998). These bacteria metabolize oxalate. Patients with CF are at increased risk of hyperoxaluria and formation of calcium-oxalate kidney stones. Conversely, an example of a pathogen acquired in CF is Clostridium difficile, which can be detected in fecal samples of $>50 \%$ of CF patients (Yahav et al. 2006).

C. difficile infection is a common occurrence with antibiotic use even in non-CF patients. Interestingly, most $\mathrm{CF}$ patients with $C$. difficile infections are asymptomatic, although a small percentage can develop colitis. A major effect of this pathogen on the gut is induction of secretory diarrhea mediated by a toxin that activates CFTR-dependent $\mathrm{Cl}$ secretion. Deficiency of functional CFTR in CF may explain the lack of symptoms in patients infected with $C$. difficile.

Besides antibiotic use, the altered luminal environment and physiology of the CF small intestine is expected to contribute to microbial dysbiosis. The healthy intestine has low levels of bacteria proximally and greater numbers distally. There are especially high levels in the colon where trillions of bacteria reside. A number of factors act to limit bacterial load in the proximal intestine (Husebye 2005). The first is acidity in the stomach, which is strong enough to kill most ingested microbes. This barrier is especially important in patients with CF because of swallowed sputum. Many patients are on acid blockers to aid digestion. Others use acid blockers because of gastroesophageal reflux. Use of these medications allows more ingested bacteria to survive passage through the stomach into the small intestine.

Another major mechanism to maintain low bacterial load in the proximal small intestine is the combined activity of gel-forming soluble 
mucins secreted from goblet cells and intestinal motility (Nieuwenhuijs et al. 1998). Mucus has complex rheological properties in that it can be adherent and at the same time acts as a lubricant. In terms of controlling bacterial load in the proximal small intestine, mucus can be thought of as acting in a manner analogous to floor sweeping compound: As dirt and debris stick to floor sweeping compound, so do bacteria bind to the complex oligosaccharides on the mucin molecules. And, as a broom easily cleans up floor sweeping compound with its bound dirt, so does intestinal motility act as the broom that sweeps the mucus-bacteria complex distally toward the large intestine. The migrating motor complex in the small intestine creates strong, caudally directed waves of smooth muscle contraction during the interdigestive period between meals. In the CF intestine the mucus is excessively viscid and intestinal motility is abnormally slow. Under these conditions, bacteria behave opportunistically by binding to the static mucus resulting in abnormal colonization and overgrowth of the small intestine.

The microbiota of the gut has important effects on the whole body's immune system especially during postnatal development (Edelman and Kasper 2008; Hansen et al. 2010; Takahashi 2010; Quigley 2011). Thus, there are important implications of microbial dysbiosis in the gut on distant organs, including the airways. Although there has been much speculation regarding the potential therapeutic manipulation of the gut microbiota in CF using probiotics, "beneficial" bacteria, there have been very few actual studies (Bruzzese et al. 2004, 2007; Weiss et al. 2010). These limited results are promising but much work remains to be done to provide convincing evidence of benefits and to define which probiotic organisms should be administered and at what concentration and dosing interval.

\section{Inflammation}

The presence of intestinal inflammation in patients with CF has received little recognition until recently. Investigations into this aspect of CF GI disease came in the wake of the epidemic of fibrosing colonopathy, a complication related to exposure to excessive amounts of pancreatic replacement therapy (PERT) seen in the early 1990s (Schwarzenberg et al. 1995). Endoscopic lavage of the CF small intestine showed increased levels of inflammatory markers in the lumen (Smyth et al. 2000). A conventional endoscopic study showed that the CF duodenum was morphologically normal but there were increased levels of several inflammatory markers in biopsied tissue (Raia et al. 2000). More recent work using video-equipped capsule endoscopy showed that morphological abnormalities including edema, erythema, mucosal breaks, and ulcerations occur in the jejunum and ileum in $>60 \%$ of CF patients (Werlin et al. 2010). That study also reported significant elevations of fecal calprotectin (a neutrophil secretory product) in many CF patients, consistent with intestinal inflammation. However, whether fecal calprotectin indicates colonic or small intestinal inflammation is not clear. Although calprotectin is well correlated with colonic inflammation, it appears less reliable for inflammation in the proximal GI tract (Summerton et al. 2002; Montalto et al. 2007, 2010; Garcia-Sanchez et al. 2010).

Crohn's disease is a multigenic inflammatory bowel disease that occurs with increased frequency in CF. Crohn's susceptibility includes genetic (MacDonald and Monteleone 2005) as well as environmental factors, such as aberrant immunological interactions with gut microflora, pathogenic bacteria, or exposure to bacterial antigens, factors that are present in patients with CF. There have been reports of an increased prevalence of Crohn's disease, up to 12.5-fold greater in patients with CF than in the general population (Lloyd-Still 1994). Incident cases must be confirmed by biopsy, because serum markers for inflammatory bowel disease may be falsely positive or negative in patients with CF (Condino et al. 2005).

Celiac disease (CD) is a destructive autoimmune condition of the small intestinal mucosa that causes malnutrition and is also more prevalent in CF (Fluge et al. 2009; Walkowiak et al. 2010). The immune response in CD is elicited by wheat gliadin and prolamine protein present in grains. The occurrence of $\mathrm{CD}$ varies from 
country to country, and this is also reflected in patients with CF. In one study, no CD patients with CF were found among subjects from Denmark, a country with a very low incidence of CD, whereas the majority of CF with CD were Swedish, from an area of Sweden with a high incidence of CD (Fluge et al. 2009). Tissue transglutaminase immunoglobulin A (TTG-IgA), a serologic marker used to screen for CD, can be elevated in patients with CF in the absence of elevated endomysial antibodies, another serologic marker, and in the absence of histological evidence of active celiac disease (Fluge et al. 2009; Hasosah et al. 2009); these patients may have falsely positive TTG-IgA or may have latent CD. Histologic diagnosis depends on finding villus atrophy and elevated intraepithelial lymphocytes. It is possible that CF predisposes to development of CD owing to impaired protein digestion, which normally degrades the gliadin antigen, as a result of pancreatic insufficiency. Alternatively, CD susceptibility in CF could be a consequence of an already inflamed intestine. In any case, because celiac disease seriously affects nutrition and it is treatable by removal of grains from the diet, it is important to screen for its occurrence in patients with CF who are growing poorly, which requires small intestinal biopsies to verify the diagnosis of CD if it is suspected on the basis of serologic testing.

\section{The Role of Acidity in the Intestinal Lumen}

Control of acidity in the intestinal lumen is important in CF for the effectiveness of PERT. Because lipase and protease are irreversibly inactivated in acid, PERT is formulated as microbeads that are enteric coated so that the enzymes can pass unharmed through the acid environment of the stomach and then dissolve in the less acidic $\mathrm{pH}$ of the duodenum. In people with EPI gastric acid is not neutralized in the proximal small intestine and PERT capsules may dissolve more distally in the small intestine than is desired. The proximal absorptive surface of the upper small bowel will be bypassed, and the mixing of bile salts with ingested triglycerides and the digested fatty acids will be aberrant. This will result in loss of normal bile salt-mediated micelle formation needed for efficient uptake of digested lipids by enterocytes. Additionally, the acidic $\mathrm{pH}$ of the proximal small intestine in CF can cause precipitation of bile salts, further impairing their ability to participate in lipid digestion and assimilation (Freudenberg et al. 2008).

Endoscopy has been used to measure $\mathrm{pH}$ in the intestinal tract of CF patients (Dalzell and Heaf 1990; Robinson et al. 1990; Barraclough and Taylor 1996). These studies showed that the proximal small intestine is more acidic and for a longer time in CF as compared with control patients. This abnormality was recently confirmed using capsule endoscopy (SmartPill), which showed that the CF small intestine was abnormally acidic for the first $30 \mathrm{~min}$ after gastric emptying (Gelfond et al. 2012), a critical time for PERT tablet dissolution and mixed micelle formation of bile salts with lipid digestion products.

\section{Malnutrition and Failure to Thrive}

A common issue in CF is maldigestion and/or malabsorption of lipids (steatorrhea) and fatsoluble vitamins (Rovner et al. 2007). The longevity of CF patients has improved dramatically over the past few decades, in good part owing to increased attention to nutritional support. Poor nutritional status in CF is highly correlated with deterioration of lung function and is a strong independent predictor of mortality as the disease progresses (Sharma et al. 2001; Steinkamp and Wiedemann 2002; Milla 2004; Courtney et al. 2007; Stallings et al. 2008). The cause and effect relationship between nutrition and airway function is not well understood (Borowitz 1996) but the correlation of the two is very strong (Stallings et al. 2008). Exocrine pancreatic insufficiency is the major cause of maldigestion, which is treated by PERT. However, even with optimal PERT, nutrition and growth is often not fully corrected (Baker et al. 2005; Borowitz et al. 2005). Furthermore, a significant proportion of pancreatic-sufficient patients have nutritional deficits as measured by low body mass index (Kumar et al. 2010). This indicates that pancreatic insufficiency cannot account for all 
nutritional issues in CF, which points to a potential problem in the small intestine.

Why fat digestion and assimilation of the digestive products is impaired in CF is only partly understood (Kalnins et al. 2007; WouthuyzenBakker et al. 2011). Normal fat digestion and assimilation involves a complex series of biochemical events in the gut lumen and in the absorptive enterocyte. Investigation of fat assimilation in CF patients, using stable isotope-labeled fatty acids, revealed there was impaired postlipolytic solubilization and/or uptake of long chain fatty acids (Kalivianakis et al. 1999), indicating that intestinal mucosal abnormalities contribute to fat malabsorption. In other work, using biopsies of human tissue, it was shown that reesterification of absorbed fatty acids and their release from enterocytes was slower in $\mathrm{CF}$ (Peretti et al. 2006). Thus, there are defects at several points in the process of fat digestion and assimilation in the CF intestine, only some of which can be readily explained by the altered luminal environment. A further influence on malnutrition may be the altered microbiota of the CF intestine. As noted above, bacteria in the intestine compete with the host for ingested nutrients, can deconjugate bile salts reducing their effectiveness at emulsifying fats for digestion and absorption (Hofmann and Mysels 1992), and the inflammation they cause can affect mucosal digestive functions (Peuhkuri et al. 2010).

\section{WHAT WE HAVE LEARNED FROM MOUSE MODELS OF CF}

Use of transgenic mouse models of CF has contributed greatly to our understanding of normal electrolyte transport mechanisms in the intestine (Seidler et al. 2009; see also Bridges 2012; Frizzell and Hanrahan 2012; Park and Lee 2012). In addition they have proved excellent models for investigation of the CF intestinal phenotype. There are many mouse models of CF, which include conventional knockouts of the Cftrgene as well as targeted mutations of $C f t r$ that are known to be disease causing in humans (for a review, see Grubb and Gabriel 1997; Guilbault et al. 2007). Unlike human CF, CF mice are pancreatic sufficient and have only mild airway involvement
(Grubb and Gabriel 1997). Thus, these models have helped elucidate the effects of intestinal abnormalities in CF without the confounding influence of EPI.

The major phenotypes in CF mouse models are intestinal obstruction, which can be lethal, and poor growth ("failure to thrive"), recapitulating symptoms and signs seen in humans with CF. The severity of the intestinal phenotype varies widely and depends on the degree of loss of functional Cftr. By comparing these different $\mathrm{CF}$ mouse lines it has been estimated that $10 \%-$ $15 \%$ of normal Cftr function is sufficient to avoid lethal intestinal problems (Guilbault et al. 2007).

A working hypothesis for the pathophysiology of CF in the intestine is the following sequence of events: (1) loss of functional CFTR results in deficient anion and fluid transport; (2) the altered luminal environment impairs turnover and clearance of mucus; (3) static mucus allow abnormal bacterial colonization (microbial dysbiosis); (4) microbial dysbiosis alters immune system behavior; and (5) immune responses further stimulate mucus production, etc. Studies using CF mice support this model, as reviewed here.

\section{Obstruction}

The first CF mouse, which was a conventional knockout mouse generated shortly after discovery of the CF gene, confirmed the essential role of CFTR in $\mathrm{Cl}^{-}$secretion in the intestine (Snouwaert et al. 1992). It was also recognized from the first that excessive mucus accumulation in the gut caused intestinal obstruction, the major phenotype of these mice. This is accompanied by increased density of goblet cells in the intestinal epithelium (Beharry et al. 2007) even though expression of the major intestinal mucin genes (Muc2, Muc3) is not elevated (Parmley and Gendler 1998; De Lisle et al. 2006).

The most severe model is knockout of Cftr resulting in total loss of expression (the Cftr ${ }^{\text {tmlUNC }}$ mouse) (Snouwaert et al. 1992). However, even in this line of CF mice the intestinal phenotype varies depending on the genetic background of the mice (Gyömörey et al. 2000; 
Norkina and De Lisle 2005), indicating the presence of modifier genes, similar to MI in human CF (see Knowles and Drumm 2012). On the C57BL/ 6 background, the phenotype is most severe and $>95 \%$ of such $\mathrm{Cftr}^{-/}$mice die of intestinal obstruction, about one-half before weaning and the rest succumbing within a week of weaning (Snouwaert et al. 1992). The majority that survive to weaning can be rescued by use of an elemental liquid diet (Peptamen) that is easily assimilated and lacks the high levels of dietary fiber found in regular solid chow (Eckman et al. 1995). An alternative is to replace the animals' drinking water with polyethylene glycol-based osmotic laxative solution, which allows the CF mice to survive on standard solid chow (Clarke et al. 1996).

Accumulation of mucus in the CF mouse intestine can be reduced by altering electrolyte transport pathways to compensate for loss of CFTR. In so-called "gut corrected" CF mice, in which human CFTR is expressed in villus cells driven by the fatty acid-binding protein promoter, the intestinal phenotype is reversed and these mice do not show intestinal mucus accumulation or obstruction (Zhou et al. 1994). There has been one study of the effects of the putative Clc2 chloride channel activator lubiprostone on the intestinal phenotype of CF mice, showing some improvement in immune activity, but unexpectedly it also increased mucus accumulation (De Lisle et al. 2010a). These data are more consistent with activation of prostaglandin receptors than activation of the $\mathrm{Clc} 2$ $\mathrm{Cl}^{-}$channel.

CF mice have also been used to test the roles of candidate modifier genes. In one study it was shown that CF mice that are also transgenic for increased expression of Clca3 (also known as Gob5) had less intestinal obstruction and improved survival (Young et al. 2007). When discovered, it was thought $\mathrm{Clca} 3$ was a calcium-regulated chloride channel, but subsequent work showed that this protein cannot be a channel because it is a soluble protein expressed in goblet cell mucin granules and released when the mucins are exocytosed (Mundhenk et al. 2006). The function of Clca3 is unknown at this time, so how it ameliorates the CF intestinal phenotype remains to be discovered. Another gene, Mucl, which encodes a membrane-associated mucin that has signal transduction capabilities, was shown to affect the severity of the intestinal phenotype in CF mice. Knockout of Mucl in CF mice resulted in reduced mucus accumulation in the large intestine (Malmberg et al. 2006), but the mechanism by which this occurred is not known. Muc1 is not quantitatively important as a mucin, so its signaling properties may affect either mucus production or solubility of gel-forming secreted mucins in the CF intestine.

\section{Infection}

Studies in CF mice support the hypothesis that static mucus allows microbial dysbiosis with increased numbers as well as loss of species diversity (Table 1) (Norkina et al. 2004). CF mice given a diet of standard chow and an osmotic laxative are more susceptible to colonization with pathogenic bacteria (Clarke et al. 2004). This study showed that mucus accumulation

Table 1. Classification of bacteria in wild-type and CF small intestines by sequencing of cloned $16 \mathrm{~S}$ polymerase chain reaction (PCR) products

\begin{tabular}{lcc}
\hline & \multicolumn{2}{c}{ Number of clones } \\
\cline { 2 - 3 } & $\begin{array}{c}\text { Wild-type } \\
\text { mouse }\end{array}$ & $\begin{array}{c}\text { CF } \\
\text { mouse }\end{array}$ \\
Classification & 37 & 2 \\
Uncultured bacteria & 20 & 0 \\
Klebsiella (oxytoca, & & \\
$\quad$ pneumoniae, and & & \\
$\quad$ granulomatis) & 13 & 0 \\
Enterobacter (aerogenes or & & \\
$\quad$ asburiae) & 5 & 95 \\
Other Enterobacteriaceae & 9 & 0 \\
Lactococcus lactis & 5 & 0 \\
Acinetobacter sp. & 4 & 0 \\
Pantoea (sp. and agglomerans) & 2 & 0 \\
Unclassified $\beta$ proteobacter & 1 & 1 \\
Helicobacter typhlonicus & 1 & 0 \\
Bacteroides acidofaciens & 1 & 0 \\
Streptococcus (gordonii or & & \\
$\quad$ parasanguinis) & 0 & 6 \\
Clostridium perfringens &
\end{tabular}

From Norkina et al. 2004; modified and reproduced, with permission, from the authors. 
in the crypt lumen creates a physical blockage that prevents access of the Paneth cell antibacterial products to the intestinal lumen proper. The interpretation was that this mucus blockage impairs innate defense mechanisms of the Paneth cell thus resulting in microbial dysbiosis. In the same strain of Cftr knockout mice maintained on a liquid diet instead of laxative, there is overt SIBO (Norkina et al. 2004) with even greater mucus accumulation and crypt lumen blockage as compared with laxative-treated mice (De Lisle et al. 2007). Importantly, SIBO occurs within 4 days of birth in CF mice (Canale-Zambrano et al. 2010) and is largely reversed by laxative treatment given at weaning (De Lisle et al. 2007; Canale-Zambrano et al. 2010).

As discussed above, slow small intestinal transit can contribute to SIBO and is common in CF patients as well as in Cftr knockout mice (De Lisle 2007). Investigation in CF mice showed that slow intestinal transit could be corrected using laxative treatment (De Lisle et al. 2007). As laxative also results in eradication of SIBO, this shows an association of dysmotility to SIBO. However, direct eradication of SIBO with broad spectrum antibiotics did not correct transit in CF mice, and in fact resulted in slowed transit in wild-type mice (De Lisle 2007). This result highlights the complex relationship between the intestinal microbiota and physiological functioning of the intestines. It is known that the composition of the intestinal microbiota, not just their numbers, is important. Germ-free animals have slowed intestinal transit and colonization with specific bacteria can either maintain slow transit (e.g., Escherichia coli) or enhance transit to usual rates (e.g., primitive anaerobic fermenters) (Caenepeel et al. 1989; Husebye et al. 2001).

To investigate the mechanisms of slowed intestinal transit in the CF mouse, ex vivo studies of intestinal tissue were performed. It was found that the circular smooth muscle from CF mouse small intestine had abnormal spontaneous activity and did not respond to cholinergic stimulation or even direct depolarization with $\mathrm{KCl}$ (De Lisle et al. 2010b). This impaired smooth muscle activity was found to be associated with elevated $\mathrm{PGE}_{2}$ levels. $\mathrm{PGE}_{2}$ has a dominant relaxant effect on the circular smooth muscle of the intestine, resulting in inhibition of normal motility programs. Interestingly, broad spectrum antibiotics that perturb the microbiota result in similar changes with increased $\mathrm{PGE}_{2}$ levels and decreased circular smooth muscle activity (De Lisle et al. 2010b). These data reinforce the important role of the microbiota in normal smooth muscle activity.

\section{Inflammation}

In addition to mucus accumulation and SIBO, CF mice have increased innate immune activity in the intestine, with increased levels of neutrophils and mast cells and up-regulation of various marker genes (Norkina et al. 2004). At this time, it is difficult to prove a direct cause and effect relationship between microbial dysbiosis and altered immune function in the CF intestine. However, there are associations between SIBO, altered immune system activity, and increased mucus production in CF mice. Laxative-treated CF mice have fewer neutrophils and mast cells and reduction of inflammation marker gene expression (De Lisle et al. 2007). If SIBO is directly eradicated with broad spectrum antibiotics, there is reduced mucus accumulation (De Lisle et al. 2006) as well as significantly less inflammation in the CF mouse intestine (Norkina et al. 2004). These results support the model that SIBO stimulates an immune response, a consequence of which is greater mucus release from goblet cells. This is not surprising, as mucus is normally protective of epithelia like that lining the intestine, and an appropriate response to bacterial overgrowth is increased mucus production. However, in the environment of the CF intestine increased mucus is detrimental because mucins do not expand properly and the aberrant mucus does not turn over and fails to carry away bacteria.

As SIBO develops, it likely increases mucus secretion via inflammatory pathways. An example of this is the elevated level of $\mathrm{PGE}_{2}$ observed in the CF mouse intestine (De Lisle et al. 2008). Prostaglandins are increased in an unusual manner in the CF mouse intestine and in the 
intestine of wild-type mice treated with broad spectrum antibiotics. In both cases there is decreased expression of the major prostaglandin degradative enzymes, prostaglandin dehydrogenase (Hpgd) and prostaglandin reductase 1 (Ptgr1) (De Lisle et al. 2008, 2010b). Interestingly, it has been shown that HPGD is a tumor suppressor gene whose expression is often decreased in GI cancer (Myung et al. 2006). It is also known that there is a greatly elevated risk of cancers of the large and small intestines in CF (Maisonneuve et al. 2003) and decreased HPGD expression is a potential candidate for this increased cancer risk in $\mathrm{CF}$.

Work crossing CF mice with other transgenic lines has shown the importance of inflammation and mucus in intestinal obstruction. In one study, CF mice were crossed with mice deficient in the lipopolysaccharide receptor (toll-like receptor 4, Tlr4) (Canale-Zambrano et al. 2010). It was found that CF mice with a single wildtype copy of Tlr4 had increased survival (less mucus obstruction) but that CF mice with no functional Tlr4 had even more rapid death in the postnatal period as compared with CF mice with two wild-type copies of Tlr4. This study illustrates the complex relationship between the immune system and CF pathologies.

\section{Electrolyte Secretion by the Intestinal Mucosa}

Studies in CF mice have shown that duodenal bicarbonate secretion by the epithelium involves two pathways: electroneutral secretion via a CFTR-assisted $\mathrm{Cl}^{-} / \mathrm{HCO}_{3}{ }^{-}$) exchange process and an electrogenic secretion of $\mathrm{HCO}_{3}{ }^{-}$via a CFTR conductance pathway (Clarke and Harline 1998). During CAMP stimulation of the CF duodenum, a small net increase in base secretion can be measured owing to cAMP inhibition of the sodium-hydrogen exchanger (NHE) activity rather than increased $\mathrm{HCO}_{3}{ }^{-}$secretion (Clarke et al. 2001). Use of talniflumate (LoMucin), a pharmacological agent that inhibits $\mathrm{Cl}^{-} /$ $\mathrm{HCO}_{3}{ }^{-}$exchange involved in intestinal $\mathrm{NaCl}$ absorption, improved survival of CF mice and tended to reduce mucus accumulation (Walker et al. 2005). Similarly, loss of $\mathrm{NaCl}$ absorption mediated by NHE in the intestine reduced the incidence of intestinal obstruction in CF mice (Bradford et al. 2009).

\section{Malnutrition and Failure to Thrive}

CF mice are an excellent model to separate the influence of EPI from other GI factors on malnutrition and failure to thrive. CF mice on the liquid diet are only $\sim 70 \%$ the body weight of wild-type mice on the same diet (Norkina et al. 2004) and weight gain can be improved by eradicating SIBO, either with broad spectrum antibiotics (Norkina et al. 2004) or less so using laxative (De Lisle et al. 2007). Interestingly, the CF mice consume 20\%-25\% less food, and pairfeeding this smaller amount of food to wildtype mice results in them being proportionately smaller than ad libitum fed mice. These observations implicate appetite and satiety control problems in the CF failure to thrive phenotype. There are some data in human CF showing alterations in appetite controlling hormones leptin and ghrelin (Stylianou et al. 2007) but the significance of such changes is not yet understood. Similar to human CF, CF mice have impaired lipolysis as well as impaired postlipolytic uptake of fatty acids, and the former was improved by inhibition of gastric acid (Bijvelds et al. 2005). A complete understanding of fat maldigestion in CF remains an important goal.

\section{CONCLUDING REMARKS}

We have gained much insight into CF pathogenesis in the intestine, in large part using $\mathrm{CF}$ mouse models to confirm and expand the limited data from CF patients. A strength of animal models is they allow more in-depth investigation and testing of potential therapeutic approaches. What we have learned also holds promise for therapeutics to improve quality of life in CF by reducing gut issues that cause "nonspecific" symptoms such as gas and bloating. For example, the many benefits of continuous osmotic laxative use in the CF mouse detailed above suggest that such use may be beneficial to prevent/alleviate GI symptoms in CF patients. There is a need for clinical trials to evaluate these agents as routine prophylaxis to 
prevent development of DIOS and potentially improve overall gut function, which may have benefits for nutrition, overall health, and quality of life for CF patients.

In addition to improving understanding of gut issues in $\mathrm{CF}$, what we have learned from investigation of the CF mouse intestine is informative about the CF airways. Even though the CF mouse does not have airway disease, all the proposed steps in CF pathogenesis in the intestine are applicable to CF airway disease. Loss of CFTR-mediated anion and fluid transport results in mucus accumulation in the $\mathrm{CF}$ airway. Static mucus allows infection of the airways in CF. Unlike the gut, the airways normally maintain a pseudosterile environment, and when infection occurs in the CF airway there is a more pronounced immune response than in the gut. But, similar to the CF gut response to microbial dysbiosis, airway infection also increases mucus production, which exacerbates the situation. And, similar to use of laxatives for intestinal issues, inhalation of the osmotic agents hypertonic saline (Wark and McDonald 2009) and mannitol (Jaques et al. 2008; Bilton et al. 2011) have been shown to stabilize or improve airway function, probably by helping hydration of mucus and restoring the periciliary fluid layer required for normal cilia beating.

An important issue that needs more investigation is the intestinal microbiota in CF. $\mathrm{CF}$ patients receive frequent antibiotics to combat airway infection, but there are no data on the impact of these treatments on the CF gut. There is a need to define the effects of such antibiotics on the gut microbiota, the functional consequences of the altered GI microbiota on intestinal function, and the influence of such changes on the whole body. For example, recent work has drawn a link between the gut microbiota and susceptibility to development of the airway disease asthma (Couzin-Frankel 2011). CF gut microbial dysbiosis likely occurs shortly after birth because the intestine is already affected at this time. Thus, the immune system in CF may develop abnormally because of microbial dysbiosis in the gut. Through altered immune system development, there is a great potential that the gut microbiota has important consequences for the CF airway. Although this concept has been considered for other diseases it is just beginning to be investigated in CF using the Cftr knockout mouse (De Lisle et al. 2011). We are in the infancy of understanding how the gut and its microbiota interact to affect health and disease states. Nevertheless, targeting the gut microbiota with prebiotics and probiotics is an upand-coming approach because microbial dysbiosis is involved in a wide range of immune disorders.

Recently, two new animal models of CF have been developed: transgenic CF pigs (Rogers et al. 2008; Stoltz et al. 2010) and ferrets (Sun et al. 2010). Importantly, these animals better reproduce airway and pancreatic pathologies characteristic of CF. They also have a higher prevalence of severe intestinal obstruction than human $\mathrm{CF}$ patients, more similar to CF mice. Although the new pig and ferret models more closely reproduce human CF disease, mouse models will continue to be useful for investigation of CF intestinal issues because they lack the complication of pancreatic insufficiency, they have a more rapid generation time, and are less expensive to maintain. What we learn investigating the small intestine can be informative of CF airway disease. The use of animal models, especially mouse models, to test potential new approaches for treatment of gastrointestinal disease may also result in benefits for therapy of CF airway disease.

\section{ACKNOWLEDGMENTS}

We appreciate the thoughtful comments of Drs. Daniel Gelfond and Daniel Leung. Work in R.C.D.'s laboratory is supported by the Cystic Fibrosis Foundation and the National Institutes of Health (AI083479).

\section{REFERENCES}

* Reference is also in this collection.

Baker SS, Borowitz D, Duffy L, Fitzpatrick L, Gyamfi J, Baker RD. 2005. Pancreatic enzyme therapy and clinical outcomes in patients with cystic fibrosis. J Pediatr 146: $189-193$. 
The CF Intestine

Bali A, Stableforth DE, Asquith P. 1983. Prolonged smallintestinal transit time in cystic fibrosis. Br Med J (Clin Res Ed) 287: 1011-1013.

Barraclough M, Taylor CJ. 1996. Twenty-four hour ambulatory gastric and duodenal $\mathrm{pH}$ profiles in cystic fibrosis: Effect of duodenal hyperacidity on pancreatic enzyme function and fat absorption. $J$ Pediatr Gastroenterol Nutr 23: 45-50.

Beharry S, Ackerley C, Corey M, Kent G, Heng YM, Christensen H, Luk C, Yantiss RK, Nasser IA, Zaman M, et al. 2007. Long-term docosahexaenoic acid therapy in a congenic murine model of cystic fibrosis. Am J Physiol Gastrointest Liver Physiol 292: G839-G848.

Bhardwaj S, Canlas K, Kahi C, Temkit M, Molleston J, Ober M, Howenstine M, Kwo PY. 2009. Hepatobiliary abnormalities and disease in cystic fibrosis: Epidemiology and outcomes through adulthood. J Clin Gastroenterol 43: 858-864.

Bhat P, Albert MJ, Rajan D, Ponniah J, Mathan VI, Baker SJ. 1980. Bacterial flora of the jejunum: A comparison of luminal aspirate and mucosal biopsy. J Med Microbiol 13: $247-256$.

Bijvelds MJ, Bronsveld I, Havinga R, Sinaasappel M, De Jonge HR, Verkade HJ. 2005. Fat absorption in cystic fibrosis mice is impeded by defective lipolysis and postlipolytic events. Am J Physiol Gastrointest Liver Physiol 288: G646-G653.

Bijvelds MJ, Bot AG, Escher JC, De Jonge HR. 2009. Activation of intestinal $\mathrm{Cl}$ - secretion by lubiprostone requires the cystic fibrosis transmembrane conductance regulator. Gastroenterology 137: 976-985.

Bilton D, Robinson P, Cooper P, Gallagher CG, Kolbe J, Fox H, Jaques A, Charlton B. 2011. Inhaled dry powder mannitol in cystic fibrosis: An efficacy and safety study. Eur Respir J 38: 1071-1080.

Blackman SM, Deering-Brose R, McWilliams R, Naughton K, Coleman B, Lai T, Algire M, Beck S, HooverFong J, Hamosh A, et al. 2006. Relative contribution of genetic and nongenetic modifiers to intestinal obstruction in cystic fibrosis. Gastroenterology 131: 1030-1039.

Borowitz D. 1996. The interrelationship of nutrition and pulmonary function in patients with cystic fibrosis. Curr Opin Pulm Med 2: 457-461.

Borowitz D, Durie PR, Clarke LL, Werlin SL, Taylor CJ, Semler J, De Lisle RC, Lewindon PJ, Lichtman SM, Sinaasappel M, et al. 2005. Gastrointestinal outcomes and confounders in cystic fibrosis. J Pediatr Gastroenterol Nutr 41: 273-285.

Braden B. 2009. Methods and functions: Breath tests. Best Pract Res Clin Gastroenterol 23: 337-352.

Bradford EM, Sartor MA, Gawenis LR, Clarke LL, Shull GE. 2009. Reduced NHE3-mediated $\mathrm{Na}^{+}$absorption increases survival and decreases the incidence of intestinal obstructions in cystic fibrosis mice. Am J Physiol Gastrointest Liver Physiol 296: G886-G898.

* Bridges RJ. 2012. Mechanisms of bicarbonate secretion: Lessons from the airways. Cold Spring Harb Perspect Med 2: a015016.

Bruzzese E, Raia V, Gaudiello G, Polito G, Buccigrossi V, Formicola V, Guarino A. 2004. Intestinal inflammation is a frequent feature of cystic fibrosis and is reduced by probiotic administration. Aliment Pharmacol Ther 20: 813-819.

Bruzzese E, Raia V, Spagnuolo MI, Volpicelli M, De MG, Maiuri L, Guarino A. 2007. Effect of Lactobacillus GG supplementation on pulmonary exacerbations in patients with cystic fibrosis: A pilot study. Clin Nutr 26: $322-328$.

Caenepeel P, Janssens J, Vantrappen G, Eyssen H, Coremans G. 1989. Interdigestive myoelectric complex in germ-free rats. Dig Dis Sci 34: 1180-1184.

Canale-Zambrano JC, Auger ML, Haston CK. 2010. Tolllike receptor-4 genotype influences the survival of cystic fibrosis mice. Am J Physiol Gastrointest Liver Physiol 299: G381-G390.

Carey MC. 1984. Bile acids and bile salts: Ionization and solubility properties. Hepatology 4: 66S-71S.

Cipolli M, Castellani C, Wilcken B, Massie J, McKay K, Gruca M, Tamanini A, Assael MB, Gaskin K. 2007. Pancreatic phenotype in infants with cystic fibrosis identified by mutation screening. Arch Dis Child 92: 842-846.

Clarke LL, Harline MC. 1998. Dual role of CFTR in cAMPstimulated $\mathrm{HCO}_{3}^{-}$secretion across murine duodenum. Am J Physiol Gastrointest Liver Physiol 274: G718-G726.

Clarke LL, Gawenis LR, Franklin CL, Harline MC. 1996. Increased survival of CFTR knockout mice with an oral osmotic laxative. Lab Anim Sci 46: 612-618.

Clarke LL, Stien X, Walker NM. 2001. Intestinal bicarbonate secretion in cystic fibrosis mice. JOP 2: 263-267.

Clarke LL, Gawenis LR, Bradford EM, Judd LM, Boyle KT, Simpson JE, Shull GE, Tanabe H, Ouellette AJ, Franklin CL, et al. 2004. Abnormal Paneth cell granule dissolution and compromised resistance to bacterial colonization in the intestine of CF mice. Am J Physiol Gastrointest Liver Physiol 286: G1050-G1058.

Cleghorn GJ, Stringer DA, Forstner GG, Durie PR. 1986. Treatment of distal intestinal obstruction syndrome in cystic fibrosis with a balanced intestinal lavage solution. Lancet 1: 8-11.

Colombo C, Russo MC, Zazzeron L, Romano G. 2006. Liver disease in cystic fibrosis. J Pediatr Gastroenterol Nutr 43: S49-S55.

Condino AA, Hoffenberg EJ, Accurso F, Penvari C, Anthony M, Gralla J, O'Connor JA. 2005. Frequency of ASCA seropositivity in children with cystic fibrosis. $J$ Pediatr Gastroenterol Nutr 41: 23-26.

Cotter PD. 2011. Small intestine and microbiota. Curr Opin Gastroenterol 27: 99-105.

Courtney JM, Bradley J, McCaughan J, O'Connor TM, Shortt C, Bredin CP, Bradbury I, Elborn JS. 2007. Predictors of mortality in adults with cystic fibrosis. Pediatr Pulmonol 42: 525-532.

Couzin-Frankel J. 2011. Bacteria and asthma: Untangling the links. Science 330: 1168-1169.

Cuppoletti J, Malinowska DH, Tewari KP, Li QJ, Sherry AM, Patchen ML, Ueno R. 2004. SPI-0211 activates T84 cell chloride transport and recombinant human ClC-2 chloride currents. Am J Physiol Cell Physiol 287: C1173C1183.

Dalzell AM, Heaf DP. 1990. Oro-caecal transit time and intra-luminal $\mathrm{pH}$ in cystic fibrosis patients with distal 
R.C. De Lisle and D. Borowitz

intestinal obstruction syndrome. Acta Univ Carol [Med] (Praha) 36: 159-160.

Dalzell AM, Freestone NS, Billington D, Heaf DP. 1990. Small intestinal permeability and orocaecal transit time in cystic fibrosis. Arch Dis Child 65: 585-588.

De Lisle RC. 2007. Altered transit and bacterial overgrowth in the cystic fibrosis mouse small intestine. Am J Physiol Gastrointest Liver Physiol 293: G104-G111.

De Lisle RC, Roach EA, Norkina O. 2006. Eradication of small intestinal bacterial overgrowth in the cystic fibrosis mouse reduces mucus accumulation. J Pediatr Gastroenterol Nutr 42: 46-52.

De Lisle RC, Roach E, Jansson K. 2007. Effects of laxative and $\mathrm{N}$-acetylcysteine on mucus accumulation, bacterial load, transit, and inflammation in the cystic fibrosis mouse small intestine. Am J Physiol Gastrointest Liver Physiol 293: G577-G584.

De Lisle RC, Meldi L, Flynn M, Jansson K. 2008. Altered eicosanoid metabolism in the cystic fibrosis mouse small intestine. J Pediatr Gastroenterol Nutr 47: 406-416.

De Lisle RC, Mueller R, Roach E. 2010a. Lubiprostone ameliorates the cystic fibrosis mouse intestinal phenotype. BMC Gastroenterol 10: 107.

De Lisle RC, Sewell R, Meldi L. 2010b. Enteric circular muscle dysfunction in the cystic fibrosis mouse small intestine. Neurogastroenterol Motil 22: 341-e87.

De Lisle RC, Mueller R, Boyd M. 2011. Impaired mucosal barrier function in the small intestine of the cystic fibrosis mouse. J Pediatr Gastroenterol Nutr 53: 371-379.

Duytschaever G, Huys G, Bekaert M, Boulanger L, De BK, Vandamme P. 2012. Dysbiosis of bifidobacteria and Clostridium cluster XIVa in the cystic fibrosis fecal microbiota. J Cyst Fibros doi: 10.1016/j.jcf.2012.10.003.

Eckman EA, Cotton CU, Kube DM, Davis PB. 1995. Dietary changes improve survival of CFTR S489X homozygous mutant mouse. Am J Physiol Lung Cell Mol Physiol 269: L625-L630.

Edelman SM, Kasper DL. 2008. Symbiotic commensal bacteria direct maturation of the host immune system. Curr Opin Gastroenterol 24: 720-724.

Escobar H, Perdomo M, Vasconez F, Camarero C, del Olmo MT, Suarez L. 1992. Intestinal permeability to 51Cr-EDTA and orocecal transit time in cystic fibrosis. Pediatr Gastroenterol Nutr 14: 204-207.

Feingold J, Guilloud-Bataille M. 1999. Genetic comparisons of patients with cystic fibrosis with or without meconium ileus. Clinical Centers of the French CF Registry. Ann Genet 42: 147-150.

* Ferec C, Cutting GR. 2012. Assessing the disease-liability of mutations in CFTR. Cold Spring Harb Perspect Med 2: a009480.

Fluge G, Olesen HV, Gilljam M, Meyer P, Pressler T, Storrosten OT, Karpati F, Hjelte L. 2009. Co-morbidity of cystic fibrosis and celiac disease in Scandinavian cystic fibrosis patients. J Cyst Fibros 8: 198-202.

Freudenberg F, Broderick AL, Yu BB, Leonard MR, Glickman JN, Carey MC. 2008. Pathophysiological basis of liver disease in cystic fibrosis employing a $\Delta \mathrm{F} 508$ mouse model. Am J Physiol Gastrointest Liver Physiol 294: G1411-G1420.
Fridge JL, Conrad C, Gerson L, Castillo RO, Cox K. 2007. Risk factors for small bowel bacterial overgrowth in cystic fibrosis. J Pediatr Gastroenterol Nutr 44: 212-218.

* Frizzell RA, Hanrahan JW. 2012. Physiology of epithelial chloride and fluid secretion. Cold Spring Harb Perspect Med 2: a009563.

Garcia MAS, Yang N, Quinton PM. 2009. Normal mouse intestinal mucus release requires cystic fibrosis transmembrane regulator-dependent bicarbonate secretion. J Clin Invest 119: 2613-2622.

Garcia-Sanchez V, Iglesias-Flores E, Gonzalez R, Gisbert JP, Gallardo-Valverde JM, Gonzalez-Galilea A, NaranjoRodriguez A, de Dios-Vega JF, Muntane J, GomezCamacho F. 2010. Does fecal calprotectin predict relapse in patients with Crohn's disease and ulcerative colitis? J Crohns Colitis 4: 144-152.

Gelfond D, Ma C, Semler J, Borowitz D. 2012. Intestinal pH and gastrointestinal transit profiles in cystic fibrosis patients measured by wireless motility capsule. Dig Dis Sci doi: 10.1007/s10620-012-2209-1.

Gill SR, Pop M, Deboy RT, Eckburg PB, Turnbaugh PJ, Samuel BS, Gordon JI, Relman DA, Fraser-Liggett CM, Nelson KE. 2006. Metagenomic analysis of the human distal gut microbiome. Science 312: 1355-1359.

Grubb BR, Gabriel SE. 1997. Intestinal physiology and pathology in gene-targeted mouse models of cystic fibrosis. Am J Physiol Gastrointest Liver Physiol 273: G258-G266.

Guilbault C, Saeed Z, Downey GP, Radzioch D. 2007. Cystic fibrosis mouse models. Am J Respir Cell Mol Biol 36: 1-7.

Gyömörey K, Rozmahel R, Bear CE. 2000. Amelioration of intestinal disease severity in cystic fibrosis mice is associated with improved chloride secretory capacity. Pediatr Res 48: 731-734.

Hansen J, Gulati A, Sartor RB. 2010. The role of mucosal immunity and host genetics in defining intestinal commensal bacteria. Curr Opin Gastroenterol 26: 564-571.

Hasosah M, Davidson G, Jacobson K. 2009. Persistent elevated tissue-transglutaminase in cystic fibrosis. J Paediatr Child Health 45: 172-173.

Hofmann AF, Mysels KJ. 1992. Bile acid solubility and precipitation in vitro and in vivo: The role of conjugation, $\mathrm{pH}$, and $\mathrm{Ca}^{2+}$ ions. J Lipid Res 33: 617-626.

Houwen RH, van der Doef HP, Sermet I, Munck A, Hauser B, Walkowiak J, Robberecht E, Colombo C, Sinaasappel M, Wilschanski M. 2010. Defining DIOS and constipation in cystic fibrosis with a multicentre study on the incidence, characteristics, and treatment of DIOS. $J$ Pediatr Gastroenterol Nutr 50: 38-42.

Husebye E. 2005. The pathogenesis of gastrointestinal bacterial overgrowth. Chemotherapy 51: 1-22.

Husebye E, Hellstrom PM, Sundler F, Chen J, Midtvedt T. 2001. Influence of microbial species on small intestinal myoelectric activity and transit in germ-free rats. $A m J$ Physiol Gastrointest Liver Physiol 280: G368-G380.

Jakab RL, Collaco AM, Ameen NA. 2011. Physiologic relevance of cell-specific distribution patterns of CFTR NKCC1, NBCe1, and NHE3 along the crypt-villus axis in the intestine. Am J Physiol Gastrointest Liver Physiol 300: G82-G98.

Jaques A, Daviskas E, Turton JA, Turton JA, McKay K, Cooper P, Stirling RG, Robertson CF, Bye PT, Lesouef PN, 
et al. 2008. Inhaled mannitol improves lung function in cystic fibrosis. Chest 133: 1388-1396.

Joo NS, Wine JJ, Cuthbert AW. 2009. Lubiprostone stimulates secretion from tracheal submucosal glands of sheep, pigs, and humans. Am J Physiol Lung Cell Mol Physiol 296: L811-L824.

Kalivianakis M, Minich DM, Bijleveld CM, Van Aalderen WM, Stellaard F, Laseur M, Vonk RJ, Verkade HJ. 1999. Fat malabsorption in cystic fibrosis patients receiving enzyme replacement therapy is due to impaired intestinal uptake of long-chain fatty acids. Am J Clin Nutr 69: 127-134.

Kalnins D, Durie PR, Pencharz P. 2007. Nutritional management of cystic fibrosis patients. Curr Opin Clin Nutr Metab Care 10: 348-354.

* Knowles MR, Drumm M. 2012. The influence of genetics on cystic fibrosis phenotypes. Cold Spring Harb Perspect Med 2: a009548.

Kopelman H, Durie P, Gaskin K, Weizman Z, Forstner G. 1985. Pancreatic fluid secretion and protein hyperconcentration in cystic fibrosis. N Engl J Med 312: 329-334.

Kopelman H, Corey M, Gaskin K, Durie P, Weizman Z, Forstner G. 1988. Impaired chloride secretion, as well as bicarbonate secretion, underlies the fluid secretory defect in the cystic fibrosis pancreas. Gastroenterology 95: 349-355.

Kumar M, Potter E, Berschback N, McColley SA. 2010. Nutritional status in children with pancreatic sufficient cystic fibrosis. Pediatr Pulmonol 45(Suppl 33): 412 (abstract).

Lewindon PJ, Robb TA, Moore DJ, Davidson GP, Martin AJ. 1998. Bowel dysfunction in cystic fibrosis: Importance of breath testing. J Paediatr Child Health 34: 79-82.

Lindblad A, Glaumann H, Strandvik B. 1999. Natural history of liver disease in cystic fibrosis. Hepatology 30: $1151-1158$.

Lisowska A, Wojtowicz J, Walkowiak J. 2009. Small intestine bacterial overgrowth is frequent in cystic fibrosis: Combined hydrogen and methane measurements are required for its detection. Acta Biochim Pol 56: 631-634.

Lisowska A, Madry E, Pogorzelski A, Szydlowski J, Radzikowski A, Walkowiak J. 2010. Small intestine bacterial overgrowth does not correspond to intestinal inflammation in cystic fibrosis. Scand J Clin Lab Invest 70: 322-326.

Lloyd-Still JD. 1994. Crohn's disease and cystic fibrosis. Dig Dis Sci 39: 880-885.

MacDonald TT, Monteleone G. 2005. Immunity, inflammation, and allergy in the gut. Science 307: 1920-1925.

Madan JC, Koestler DC, Stanton BA, Davidson L, Moulton LA, Housman ML, Moore JH, Guill MF, Morrison HG, Sogin ML, et al. 2012. Serial analysis of the gut and respiratory microbiome in cystic fibrosis in infancy: Interaction between intestinal and respiratory tracts and impact of nutritional exposures. MBio 3: e0025112-12.

Maisonneuve P, FitzSimmons SC, Neglia JP, Campbell PW III, Lowenfels AB. 2003. Cancer risk in nontransplanted and transplanted cystic fibrosis patients: A 10-year study. J Natl Cancer Inst 95: 381-387.

Malmberg EK, Noaksson KA, Phillipson M, Johansson ME, Hinojosa-Kurtzberg M, Holm L, Gendler SJ, Hans- son GC. 2006. Increased levels of mucins in the cystic fibrosis mouse small intestine and modulator effects of the Muc1 mucin expression. Am J Physiol Gastrointest Liver Physiol 291: G203-G210.

Milla CE. 2004. Association of nutritional status and pulmonary function in children with cystic fibrosis. Curr Opin Pulm Med 10: 505-509.

Montalto M, Santoro L, Curigliano V, D'Onofrio F, Cammarota G, Panunzi S, Ricci R, Gallo A, Grieco A, Gasbarrini A, et al. 2007. Faecal calprotectin concentrations in untreated coeliac patients. Scand J Gastroenterol 42: 957-961.

Montalto M, Gallo A, Ianiro G, Santoro L, D'Onofrio F, Ricci R, Cammarota G, Covino M, Vastola M, Gasbarrini A, et al. 2010. Can chronic gastritis cause an increase in fecal calprotectin concentrations? World J Gastroenterol 16: 3406-3410.

Mundhenk L, Alfalah M, Elble RC, Pauli BU, Naim HY, Gruber AD. 2006. Both cleavage products of the mCLCA3 protein are secreted soluble proteins. J Biol Chem 281: 30072-30080.

Murphy MS, Brunetto AL, Pearson AD, Ghatei MA, Nelson R, Eastham EJ, Bloom SR, Green AA. 1992. Gut hormones and gastrointestinal motility in children with cystic fibrosis. Dig Dis Sci 37: 187-192.

Myung SJ, Rerko RM, Yan M, Platzer P, Guda K, Dotson A, Lawrence E, Dannenberg AJ, Lovgren AK, Luo G, et al. 2006. 15-Hydroxyprostaglandin dehydrogenase is an in vivo suppressor of colon tumorigenesis. Proc Natl Acad Sci 103: 12098-12102.

Nieuwenhuijs VB, Verheem A, Duijvenbode-Beumer H, Visser MR, Verhoef J, Gooszen HG, Akkermans LM. 1998. The role of interdigestive small bowel motility in the regulation of gut microflora, bacterial overgrowth, and bacterial translocation in rats. Ann Surg 228: $188-193$.

Norkina O, De Lisle RC. 2005. Potential genetic modifiers of the cystic fibrosis intestinal inflammatory phenotype on mouse chromosomes 1, 9, and 10. BMC Genet 6: 29.

Norkina O, Burnett TG, De Lisle RC. 2004. Bacterial overgrowth in the cystic fibrosis transmembrane conductance regulator null mouse small intestine. Infect Immun 72: 6040-6049.

O'Brien S, Mulcahy H, Fenlon H, O'Broin A, Casey M, Burke A, FitzGerald MX, Hegarty JE. 1993. Intestinal bile acid malabsorption in cystic fibrosis. Gut 34: $1137-$ 1141.

O’Brien CE, Anderson PJ, Stowe CD. 2010. Use of the chloride channel activator lubiprostone for constipation in adults with cystic fibrosis: A case series (March). Ann Pharmacother 44: 577-581.

* Park HW, Lee MG. 2012. Transepithelial bicarbonate secretion: Lessons from the pancreas. Cold Spring Harb Perspect Med 2: a009571.

Parmley RR, Gendler SJ. 1998. Cystic fibrosis mice lacking mucl have reduced amounts of intestinal mucus. J Clin Invest 102: $1798-1806$.

Peretti N, Roy CC, Drouin E, Seidman E, Brochu P, Casimir G, Levy E. 2006. Abnormal intracellular lipid processing contributes to fat malabsorption in cystic fibrosis patients. Am J Physiol Gastrointest Liver Physiol 290: G609-G615. 
R.C. De Lisle and D. Borowitz

Peuhkuri K, Vapaatalo H, Korpela R. 2010. Even low-grade inflammation impacts on small intestinal function. World J Gastroenterol 16: 1057-1062.

Qin J, Li R, Raes J, Arumugam M, Burgdorf KS, Manichanh C, Nielsen T, Pons N, Levenez F, Yamada T, et al. 2010a. A human gut microbial gene catalogue established by metagenomic sequencing. Nature 464: 59-65.

Qin X, Sheth SU, Sharpe SM, Dong W, Lu Q, Xu D, Deitch EA. 2010b. The mucus layer is critical in protecting against ischemia/reperfusion-mediated gut injury and in the restitution of gut barrier function. Shock 35: $275-281$.

Quigley EM. 2011. Microflora modulation of motility J Neurogastroenterol Motil 17: 140-147.

Raia V, Maiuri L, De Ritis G, De Vizia B, Vacca L, Conte R, Auricchio S, Londei M. 2000. Evidence of chronic inflammation in morphologically normal small intestine of cystic fibrosis patients. Pediatr Res 47: 344-350.

Robinson PJ, Smith AL, Sly PD. 1990. Duodenal pH in cystic fibrosis and its relationship to fat malabsorption. Dig Dis Sci 35: 1299-1304.

Rogers CS, Stoltz DA, Meyerholz DK, Ostedgaard LS, Rokhlina T, Taft PJ, Rogan MP, Pezzulo AA, Karp PH Itani OA, et al. 2008. Disruption of the CFTR gene produces a model of cystic fibrosis in newborn pigs. Science 321: 1837-1841.

Rovner AJ, Stallings VA, Schall JI, Leonard MB, Zemel BS. 2007. Vitamin D insufficiency in children, adolescents, and young adults with cystic fibrosis despite routine oral supplementation. Am J Clin Nutr 86: 1694-1699.

Rubinstein S, Moss R, Lewiston N. 1986. Constipation and meconium ileus equivalent in patients with cystic fibrosis. Pediatrics 78: 473-479.

Schwarzenberg SJ, Wielinski CL, Shamieh I, Carpenter BL, Jessurun J, Weisdorf SA, Warwick WJ, Sharp HL. 1995. Cystic fibrosis-associated colitis and fibrosing colonopathy. J Pediatr 127: 565-570.

Seidler U, Singh A, Chen M, Cinar A, Bachmann O, Zheng W, Wang J, Yeruva S, Riederer B. 2009. Knockout mouse models for intestinal electrolyte transporters and regulatory PDZ adaptors: New insights into cystic fibrosis, secretory diarrhoea and fructose-induced hypertension. Exp Physiol 94: 175-179.

Sekirov I, Russell SL, Antunes LC, Finlay BB. 2010. Gut microbiota in health and disease. Physiol Rev 90: 859-904.

Sharma R, Florea VG, Bolger AP, Doehner W, Florea ND, Coats AJ, Hodson ME, Anker SD, Henein MY. 2001. Wasting as an independent predictor of mortality in patients with cystic fibrosis. Thorax 56: 746-750.

Sidhu H, Hoppe B, Hesse A, Tenbrock K, Bromme S, Rietschel E, Peck AB. 1998. Absence of Oxalobacter formigenes in cystic fibrosis patients: A risk factor for hyperoxaluria. Lancet 352: 1026-1029.

Singh VV, Toskes PP. 2003. Small bowel bacterial overgrowth: Presentation, diagnosis, and treatment. Curr Gastroenterol Rep 5: 365-372.

Smyth RL, Croft NM, O'Hea U, Marshall TG, Ferguson A. 2000. Intestinal inflammation in cystic fibrosis. Arch Dis Child 82: 394-399.

Snouwaert JN, Brigman KK, Latour AM, Malouf NN, Boucher RC, Smithies O, Koller BH. 1992. An animal model for cystic fibrosis made by gene targeting. Science 257: 1083-1088.

Stallings VA, Stark LJ, Robinson KA, Feranchak AP, Quinton H. 2008. Evidence-based practice recommendations for nutrition-related management of children and adults with cystic fibrosis and pancreatic insufficiency: Results of a systematic review. J Am Diet Assoc 108: 832-839.

Steinkamp G, Wiedemann B. 2002. Relationship between nutritional status and lung function in cystic fibrosis: Cross sectional and longitudinal analyses from the German CF quality assurance (CFQA) project. Thorax 57: 596-601.

Stoltz DA, Meyerholz DK, Pezzulo AA, Ramachandran S, Rogan MP, Davis GJ, Hanfland RA, Wohlford-Lenane C, Dohrn CL, Bartlett JA, et al. 2010. Cystic fibrosis pigs develop lung disease and exhibit defective bacterial eradication at birth. Sci Transl Med 2: 29ra31.

Strong TV, Boehm K, Collins FS. 1994. Localization of cystic fibrosis transmembrane conductance regulator $\mathrm{mRNA}$ in the human gastrointestinal tract by in situ hybridization. J Clin Invest 93: 347-354.

Stylianou C, Galli-Tsinopoulou A, Koliakos G, Fotoulaki M, Nousia-Arvanitakis S. 2007. Ghrelin and leptin levels in young adults with cystic fibrosis: Relationship with body fat. J Cyst Fibros 6: 293-296.

Summerton CB, Longlands MG, Wiener K, Shreeve DR. 2002. Faecal calprotectin: A marker of inflammation throughout the intestinal tract. Eur J Gastroenterol Hepatol 14: 841-845.

Sun X, Sui H, Fisher JT, Yan Z, Liu X, Cho HJ, Joo NS, Zhang Y, Zhou W, Yi Y, et al. 2010. Disease phenotype of a ferret CFTR-knockout model of cystic fibrosis. J Clin Invest 120: 3149-3160.

Takahashi K. 2010. Interaction between the intestinal immune system and commensal bacteria and its effect on the regulation of allergic reactions. Biosci Biotechnol Biochem 74: 691-695.

van der Doef HP, Kokke FT, Beek FJ, Woestenenk JW, Froeling SP, Houwen RH. 2010. Constipation in pediatric cystic fibrosis patients: An underestimated medical condition. J Cyst Fibros 9: 59-63.

* Verdugo P. 2012. Supramolecular dynamics of mucus. Cold Spring Harb Perspect Med 2: a009597.

Walker NM, Simpson JE, Levitt RC, Boyle KT, Clarke LL. 2005. Talniflumate increases survival in a cystic fibrosis mouse model of distal intestinal obstructive syndrome (DIOS). J Pharmacol Exp Ther 317: 275-283.

Walkowiak J, Blask-Osipa A, Lisowska A, Oralewska B, Pogorzelski A, Cichy W, Sapiejka E, Kowalska M, Korzon M, Szaflarska-Poplawska A. 2010. Cystic fibrosis is a risk factor for celiac disease. Acta Biochim Pol 57: 115-118.

Wark P, McDonald VM. 2009. Nebulised hypertonic saline for cystic fibrosis. Cochrane Database Syst Rev CD001506.

Weiss B, Bujanover Y, Yahav Y, Vilozni D, Fireman E, Efrati O. 2010. Probiotic supplementation affects pulmonary exacerbations in patients with cystic fibrosis: A pilot study. Pediatr Pulmonol 45: 536-540.

Werlin SL, Benuri-Silbiger I, Kerem E, Adler SN, Goldin E, Zimmerman J, Malka N, Cohen L, Armoni S, YatzkanIsraelit Y, et al. 2010. Evidence of intestinal inflammation 


\section{The CF Intestine}

in patients with cystic fibrosis. J Pediatr Gastroenterol Nutr 51: 304-308.

* Wilschanski M, Novak I. 2013. The cystic fibrosis of exocrine pancreas. Cold Spring Harb Perspect Med 3: a 009746 .

Wood JD. 2010. Enteric nervous system: Sensory physiology, diarrhea and constipation. Curr Opin Gastroenterol 26: $102-108$.

Wouthuyzen-Bakker M, Bodewes FA, Verkade HJ. 2011. Persistent fat malabsorption in cystic fibrosis; lessons from patients and mice. J Cyst Fibros 10: 150-158.
Yahav J, Samra Z, Blau H, Dinari G, Chodick G, Shmuely H. 2006. Helicobacter pylori and Clostridium difficile in cystic fibrosis patients. Dig Dis Sci 51: 2274-2279.

Young FD, Newbigging S, Choi C, Keet M, Kent G, Rozmahel RF. 2007. Amelioration of cystic fibrosis intestinal mucous disease in mice by restoration of mCLCA3. Gastroenterology 133: 1928-1937.

Zhou L, Dey CR, Wert SE, DuVall MD, Frizzell RA, Whitsett JA. 1994. Correction of lethal intestinal defect in a mouse model of cystic fibrosis by human CFTR. Science 266: 1705-1708. 


\section{$\&_{\mathrm{CSH}}^{\infty} \&$ Cold Spring Harbor

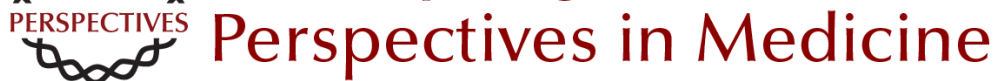

\section{The Cystic Fibrosis Intestine}

Robert C. De Lisle and Drucy Borowitz

Cold Spring Harb Perspect Med 2013; doi: 10.1101/cshperspect.a009753 originally published online June 20, 2013

\section{Subject Collection Cystic Fibrosis}

Antibiotic and Anti-Inflammatory Therapies for Cystic Fibrosis James F. Chmiel, Michael W. Konstan and J. Stuart Elborn

Structure and Function of the Mucus Clearance System of the Lung

Brenda M. Button and Brian Button

New Pulmonary Therapies Directed at Targets

Other than CFTR Scott H. Donaldson and Luis Galietta

The Cystic Fibrosis Airway Microbiome Susan V. Lynch and Kenneth D. Bruce

Cystic Fibrosis Transmembrane Conductance Regulator (ABCC7) Structure John F. Hunt, Chi Wang and Robert C. Ford

Status of Fluid and Electrolyte Absorption in Cystic Fibrosis

M.M. Reddy and M. Jackson Stutts

The Influence of Genetics on Cystic Fibrosis

Phenotypes

Michael R. Knowles and Mitchell Drumm

Perspectives on Mucus Properties and Formation

--Lessons from the Biochemical World

Daniel Ambort, Malin E.V. Johansson, Jenny K.

Gustafsson, et al.
The Cystic Fibrosis Intestine

Robert C. De Lisle and Drucy Borowitz

Cystic Fibrosis Transmembrane Regulator Correctors and Potentiators

Steven M. Rowe and Alan S. Verkman

The Cystic Fibrosis of Exocrine Pancreas

Michael Wilschanski and Ivana Novak

Dynamics Intrinsic to Cystic Fibrosis

Transmembrane Conductance Regulator Function and Stability

P. Andrew Chong, Pradeep Kota, Nikolay V.

Dokholyan, et al.

The Cystic Fibrosis Gene: A Molecular Genetic

Perspective

Lap-Chee Tsui and Ruslan Dorfman

The CFTR Ion Channel: Gating, Regulation, and

Anion Permeation

Tzyh-Chang Hwang and Kevin L. Kirk

Assessing the Disease-Liability of Mutations in CFTR

Claude Ferec and Garry R. Cutting

Supramolecular Dynamics of Mucus

Pedro Verdugo

For additional articles in this collection, see http://perspectivesinmedicine.cshlp.org/cgi/collection/ 